DOI: 10.1515/pof-2015-0006

VOLUME 7, ISSUE 1, 2015

ISSN: $2036-5438$

\title{
Federalism in Pakistan: Of Promises and Perils
}

by

Zubair Shahid*

Perspectives on Federalism, Vol. 7, issue 1, 2015 


\section{Abstract}

This paper presents the case of Pakistan, which is also broadly illustrative of the issues concerning federalism and subnational empowerment in developing countries characterized by unconsolidated political systems and enhanced constitutionalism. In the course of the analysis, this paper examines the dynamics and determinants of federalist/subnational politics in Pakistan, the formal constitutional and ordinance frameworks stipulated in support of federalism and subnational governance. The analysis shall be focused on the Local Governments Ordinance of 2001 and the $18^{\text {th }}$ Constitutional Amendment, as these have been the most substantive attempts at subnational constitutionalism that were instituted under opposing political systems, and the extent to which they have enabled greater prospects for a stable federation while also examining the challenges that the radical departure under the $18^{\text {th }}$ Constitutional Amendment put forth.

\section{Key-words}

Federalism, Decentralization, Fiscal federalism, Inter-governmental relations, Public finance, Subnational governance, Reform consolidation, State building 


\section{Introduction}

Against the backdrop of globalization, increasing supra-national influences, democratization waves, and ever-increasing avenues for ethnic and regional interest articulation, the reconsideration of national governance structure has emerged as an important reform agenda. This is perhaps of a greater salience in the developing contexts where a growing number of countries are increasingly revisiting or rearranging their governance structures in the virtuous pursuit of greater state cohesiveness, nation-building, good governance and democracy. These rearrangements have either involved unitary constitutional structures' transition to federal or confederal structures, or strengthening subnational governance in contexts retaining the unitary structure of governance. The challenges of diversity that the modern polity confronts can be best addressed by following the old dictum of 'e pluribis unum' in the (re)structuring of the state, whilst ensuring that the perils of greater subnational autonomy do not dominate the oft-highlighted promises. This potential paradox was identified by Alexander Hamilton in 1787 while making a statement before the New York Ratifying Commission:

\footnotetext{
"The probable evil is that the general government will be too dependent on the state legislatures, too much governed by their prejudices, and too obsequious to their humours; that the states, with every power in their hands, will make encroachments on the national authority, till the union is weakened and dissolved." - Hamilton (1787)
}

The virtues of federalism and subnational empowerment have surfaced recurrently in political as well as economic theories from the times of Madison \& Hamilton to Musgrave (1961) to Oates (2006) and Weingast (2009). The common denominator remains that in ethnically and socially heterogenous contexts, state policy is most conducive to the preferences of its constituents when a multi-tiered governance structure exists, with each level having a distinct mandate. Higher levels of government (at the central level) are more suited for the provision of nationwide public goods (such as defence) to retain the benefits of homogeniety in standards, non-excludability and scale effects, while the lower levels of the government (regional/provincial or local/municipal) are better suited in the provision 
of locally responsive public goods (waste management, local infrastructure, water and sanitation, amongst others). Distinct mandates, clearly defined functions, and adherence to the stipulated parameters by each tier of the government also enable a greater degree of targeted accountability by the citizen. As compared to a high concentration of power in a potentially exploitative centre, federalism enables diluted power among multiple tiers of government, which may also be mutually competitive horizontally and dependent vertically. From a purely political standpoint, such a dilution in the concentration of power illustrates a path to peace, order and stability especially in contexts marred by deep socio-political cleavages. From a purely economic point of view, the decentralized federal systems enable a higher responsiveness of the government to constituents rooted in greater preference revelation and access to information, as well as the benefits arising as a consequence of intergovernmental competition.

The potential perils of federalism have received relatively lesser mileage in the ongoing discourse, despite being highly influential in substantially reversing the course of the intended reforms. Federalism transcends mere administrative rearrangements, and involves substantive political rearrangement that results in limiting central autonomy in policy design, implementation and enforcement. Building upon the Hamiltonian paradox, while limited central autonomy augurs well for subnational empowerment and federalism, it also results in limiting the strategic control of the centre. This could be a detrimental feature, as decentralized entities may face higher costs of coordination as well as provision owing to scale constraints. Furthermore, if the federalism is not properly structured and the relevant interests in the decentralized scheme are averse to renegotiation on a circumstantial basis, decentralized federalism may instead result in hampering efficiency, accountability and exacerbating instability of the federation itself. This may be a consequence of greater incentives by individual subnational governance structures to expand their expenditures beyond their contribution and externalize the costs to the others or the superior governmental level(s), resulting in an overgrazing of the common fiscal resources which could have significant macroeconomic implications.

With this in context, this paper examines the experience of federalism in Pakistan, which has been characterized by potholes, detours and prospects alike. The Hamiltonian paradox discussed earlier has also been a recurrent observation in Pakistan, given a consistent divergence of the de-facto and de-jure in governance - run predominantly as a 
unitary state despite being formally a federal state. The $18^{\text {th }}$ Constitutional Amendment in 2009/10 has been a key development in substantive federalism in Pakistan, diluting the influence of a traditionally powerful centre in the favor of the provincial or subnational governments. The following sections present an evaluation of the prospects and challenges of federalism and subnational empowerment in Pakistan, especially in the aftermath of the $18^{\text {th }}$ Constitutional Amendment.

\section{Contextual overview}

The state of Pakistan was envisaged as a federal state at the time of its inception. This was partly attributable to the fact that prior to independence, the founding party continued to articulate demands for increased provincial autonomy under the British rule. In addition, the modalities employed under the Partition Plan (1946) required that the Muslim majority provinces and the Muslim members of provincial legislatures were to choose whether to remain within the Indian federation after decolonization or come together to form a federation of Pakistan. The need for federal system was also an imperative, given that the nation was essentially created on an ideological basis and not ethnic, linguistic or social basis. While being a strong point of articulation, it was important for the state to focus on addressing the heterogeneity of ethnicities, customs, language and social norms, to assure the stability of the newly created polity. Following its independence, the Government of India Act 1935 was adopted as the interim constitutional order with minor changes, while a Constituent Assembly was tasked with creating a new constitution. It must be noted that the Government of India Act 1935, as a colonial instrument, created a federal system but the distribution of authority and powers was skewed towards the centre which was held by the British. The Republic of India was also established at the same time as Pakistan in 1947, but its constitutional experience was on a different trajectory right at the outset instead of provisionally invoking the Government of India Act 1935, the Indian Independence Act 1947 was instituted as a provisional constitution that took all conducive provisions from the various Indian Councils Acts $(1858,1861,1892,1909)$ and the Government of India Acts (1919, 1935). While the first constitution for India was promulgated in 1950, Pakistan saw its first constitution coming out in 1956. A main reason for this was the political instability post 1952 which saw four governments changing in a 4 
year period hampering the consistency required for the constitutional process to get truly off the ground. The first Constitution was promulgated in 1956, which explicitly declared Pakistan as a federal state, however the centripetal impulses of power distribution persisted. Owing to the political crises that ensued in its aftermath, this constitution was abrogated in 1958 and a martial law was imposed.

This marked the beginning of the political instability that has marred the establishment of a stable political culture in Pakistan, as military governments have since ruled the country for an aggregate period of more than three decades. The first military takeover of the government occurred in 1958 with the imposition of martial law by General Ayub Khan. Under his regime, the promulgation of the second constitution took place in 1962 which was prepared by a non-representative bureaucratic body. In the aftermath of its promulgation, a legislative assembly was established and presidential elections were held in which General Ayub Khan retained his position. Following his resignation in 1969 and an intermittent transition under another military dictator, a democratically elected government took office under Zulfikar Ali Bhutto as the Prime Minister in 1971. This period of democratic rule lasted until 1977 when it was overthrown by another military chief Gen. Zia-ul-Haq, however the most important event in this democratic phase was the promulgation and ratification of a new constitution by a representative government in 1973. The Zia regime lasted from 1977 until 1988, whereby political parties were barred from actively participating in the political space until 1986 and a legislative assembly based on non-partisan elections assumed office in 1985. Democratic rule returned to the fore after 1988 until 1999, during which time the PPP and the Pakistan Muslim League (PML) alternated in incumbency for short periods. None of these two parties were able to complete their terms in both rounds of their incumbency. A military coup in October 1999 dislodged the government of PML and the government was headed by the then military chief, General Pervez Musharraf as the Chief Executive. Upon assuming the government, the Musharraf regime held the 1973 constitution in abeyance, and in its stead, introduced the Provisional Constitutional Order as the governing framework of the state. The objective of imposing the PCO was to create an institutional environment conducive for the new incumbents to pursue deep structural and political reforms, as stated in the Article 4 (1) and (2) of the PCO: 


\section{Article 4}

1. No Court, Tribunal or other authority shall call or permit to be called in question the proclamation of Emergency of 14th day of October, 1999 or any Order made in pursuance thereof.

2. No judgment, decree, writ, order or process whatsoever shall be made or issued by any court or tribunal against the Chief Executive or any authority designated by the Chief Executive

(Excerpt from the Provisional Constitutional Order, 2001)

Holding the constitution in abeyance was not directed at the abrogation of the constitution, and hence the military regime had to receive a nod of 'legitimacy' from the Supreme Court. The Supreme Court declared the coup d'etat as legitimate and necessary and gave General Musharraf a period of three years to transfer the government back under democratic civilian rule. In 2002, in line with the Supreme Court's ruling, Musharraf conducted a referendum for Presidency in which he was the sole contender which enabled him to earn an additional 5 years constitutionally mandated term as President. Soon after his referendum, President Musharraf called for general elections to elect the national and provincial legislatures, in October 2002. Prior to the elections, the Musharraf regime also instituted a Legal Framework Order (LFO, 2001) as an addendum to the PCO that ensured that the power would lie with the Presidency, regardless of the outcome of the elections for the provincial and national legislatures. The LFO also expanded the adult suffrage by lowering the voting age to 18 years as compared to a prior 22 years, which was subsequently also ratified after the 1973 constitution was put into effect in the aftermath of the elections. In 2008, as a result of fresh elections at the national and provincial levels, the government was assumed again by the civilian democratic parties, with the PPP emerging as the victor and Musharraf still retained the presidency until August 2008, when he resigned owing to the threats of impeachment. The PPP government that assumed office in 2008 was the first ever civilian government to complete its constitutionally mandated tenure of 5 years in 2013 in the country's 66 year history.

Before narrowing on to the subnational constitutionalism and substantive attempts at federalism under the LGO 2001 and the $18^{\text {th }}$ Amendment in 2010, a brief overview of similar provisions in the 1956, 1962, and the 1973 Constitutions follows ${ }^{\mathrm{I}}$. 
The 1956 Constitution in its Article I, reaffirmed the federal structure of the state, and a uni-cameral legislature under Article 43 - a Parliament including the President, the Prime Minister and a National Assembly. The number of the National Assembly members was fixed at 300, with the membership equally divided between the Eastern ${ }^{\mathrm{II}}$ and Western wings of Pakistan. Article 61 under the 1956 Constitution stipulated that all revenue collection, loan acquisition and the money mobilized for their settlement by the Federal Government would be accumulated in a Federal Consolidated Fund. All other public finance resources received by or for the federal government were to be accumulated under the Federal Public Account. Articles 77 and 78 dealt stipulated unicameral legislatures at the subnational/ provincial level whereby the provincial legislature would comprise of a Governor (Nominated Federal Representative), a Chief Minister (elected from the Provincial Assembly), and a Provincial Assembly comprising of 300 members. The unitary spirit of the 1956 Constitution could be seen in the Article 92, whereby no bill or amendment making provisions for any matters specified in a money bill, or what could involve expenditures from the Provincial Revenue pools, could be introduced without the assent and approval of the Governor. From a fiscal point of view, Article 116 stipulated that the provinces could borrow finances to the extent allowed by the provincial legislature and with the Provincial Consolidated Fund. However, the article further stipulated that the Federal Government can impose conditionalities or provide guarantees upon loans acquired by a province as it deems fit, but the provinces cannot have access to foreign sources of finance without the approval of the federal government.

The 1956 Constitution, had one important contribution that was retained in the subsequent constitutional frameworks until today - the National Finance Commission. The NFC, stipulated under Article 118, designates the President to define the parameters and modalities of distributing financial resources between the Federation and the Provinces. Subsequently, Article 119 stipulated the limits of the provincial governments to pass legislations or laws concerning inter-provincial trade, taxation, or tolls on goods manufactured on produced in their jurisdictions. This implied that the revenue generation at the subnational level was not allowed and the subnational inflows had to primarily depend on central transfers. This constitutional framework also put forth mechanisms of dispute resolution to settle central-provincial and inter-provincial disputes under Article 129. The idea was to establish consensual deliberative bodies or enabling the disputes to be 
referred to the Supreme Court or if they do not fall in the established jurisdiction of the Supreme Court, then the matter may be referred to a Special Tribunal established by the Chief Justice of the Supreme Court. In addition to this, one of the key contributions of this constitution, retained (albeit with revisions) in the subsequent constitutional frameworks was the establishment of the National Economic Council. As per the Article 199, the National Economic Council was to consist of four Federal Ministers and three Ministers from each province. Furthermore, the President had the authority to appoint a board for each province comprising of both the federal and provincial representatives to advise the Federal government on matters related to the provinces. The tenure for central and provincial assemblies under this constitution was set as three years, within which time fresh general elections had to be called.

Following its abrogation in 1958, the Ayub regime established a new constitutional body tasked with framing a new constitution. Upon its promulgation, the first departure it took from the previous order was discarding the terms 'Federal' and Islamic' from the national name, however the latter was reinstated in the First Amendment in 1963. While it retained the unicameral legislature in the same form as the preceding constitutional order, the number of members in the national legislature was limited to 156 , equally divided amongst the provinces. The provincial legislatures were also retained in the same form as stipulated in 1956, with the exception being that the elected provincial assembly seats were limited to 155 (subsequently increased to 218) and instead of the Chief Minister, the Governor was the head of the provincial government with the Provincial Assembly being a legislative body only. Article 74 of the 1962 Constitution also limited the autonomy of the provincial assembly. Under this article, any conflict between the Governor (a federal representative) and the Provincial Assembly, if ruled in favor of the Governor by the National Assembly, could enable the Governor to dissolve the assemblies (contingent upon the approval of the President). This particular provision assumed the status akin to the Sword of Damocles, which enhanced the central government's influence and authority over the provincial government. This constitutional framework was more unitary in spirit and perhaps implicitly, in form too. For instance, under the Article 131, the Central Legislature had the authority to make laws or sanction actions for some parts or the whole country, as deemed necessary for matters enumerated in the Third Schedule of the Constitution (this included national security, financial stability, and planning or coordination). In terms of the 
institutional dominance of the centre, the National Economic Council was also stipulated to comprise of presidentially nominated individuals - with no provision made for mandatory provincial representation. Finally, a stark departure from the preceding framework, was the establishment of institutions of indirect democracy. Under the Article 155, an electoral college was to be formed, whereby each province was to be divided into at least 40,000 electoral units, each of which shall serve as constituencies for the Provincial and central legislatures. These electoral units were akin to local governance structures, albeit with little functional or fiscal privileges, and were called Basic Democracies.

Following the resignation of President Ayub in 1969, a Provisional Constitutional Order was instituted along with a Legal Framework Order, until 1973 when a new constitutional framework of the country was promulgated by a popularly-elected legislature. This constitutional framework is the one still in force, and subject to 22 Amendments as of 2015. The 1973 Constitution stipulated a federal and parliamentary democracy, with three government tiers - central, provincial and local ${ }^{\mathrm{III}}$. The central legislature was changed from unicameral to bi-cameral, with the Senate (Upper House) and National Assembly (Lower House). The Senate was to provide an equal representation to all federating regions without any link to population, economic wealth or size, and elected by the Lower House including a few reserve seats for which nominations would come from the political parties and the executive. The Lower House/ National Assembly was to consist of elected representatives elected to represent the population as a whole, with each assembly seat representing a distinct constituency. This Constitutional framework instituted a Westminster style parliamentary democracy, albeit with a few modifications, and had three main legislative lists; the Federal Legislative List, Concurrent Legislative List, and the Provincial Legislative List. These are discussed in a greater detail in the section on the $18^{\text {th }}$ Amendment.

\section{Paradox of subnational democracy in Pakistan}

While the evolution of federalism from the constitutional/legal point of view has been briefly reviewed, it is also important to observe any structural reforms in governance that enhanced subnational influence/participation. Interestingly, the political history of Pakistan shows a paradoxically countercyclical pattern for subnational (especially, local) democracy 
(Cheema, Khan \& Myerson 2013). Thrice in the history of Pakistan, electoral democracy has been introduced at the local (Municipal) levels (1962, 1985, and 2001), which have either been rolled back or "replaced with unelected administrators" (Cheema, Khan \& Myerson 2013) once the civilian governments return. The most recent establishment of democratic local governments under the LGO 2001 during the Musharraf regime were, and predictably so, rolled back by the revived civilian democratic government at the central and provincial levels. As a result, a complete civilian tenure in government (2008-2013) elapsed without the establishment of local democratic governments, and was instead characterized by a re-bureaucratization at the local levels. With this in context, it is advantageous to examine why decentralized political governance at the local levels has been a cause championed by the military regimes and less so by the civilian democratic actors.

A popular assertion, which this research also concedes to, is that the elected local governments are established to dilute the political strength of the established political parties and to lend greater legitimacy and a consolidated alternative political base to the incumbent military regime. Elected local governments could offer a non-representative central government a vital political connection to the constituencies throughout the nation, whereby the local incumbents have a direct articulation channel with the centre which in its own interests of consolidation has an incentive to be of a greater responsiveness (Cheema et al. 2006, Myerson 2009). An illustration of this can be found in the 2001 reforms, where the non-representative centre confronted a strong entrenchment of party politics in the broader political space, especially at the central and provincial levels. The incentives of the centre were thus truly reflected in the award of progressively greater authority to local governments vis-à-vis the provincial governments. The devolution of authority under the LGO took the form of greater devolution from the provinces to the local governments, with the central scope of authority very negligibly changed.

Across all of the local governance reforms thus far in the history of Pakistan, a common feature has been the non-partisanship of the local elections. This remained the case with the 2001 LGO as well, where the partisan interests exhibited a considerable degree of resilience in their presence (even though covert), their degree of leverage over the centre or the local governments was considerably reduced. The rules against the partisan local elections, as a general idea, are an influential bargaining and incentive-maximization strategy for the non-representative centre, as it enables a selective enforcement of the rules. 
This feature of the local governance structures established under the military regimes offers some explanation of the civilian democratic governments' aversion to allow the local governance structures to exist. Rather intuitive, the mainstream political parties in Pakistan (PML and PPP) saw the local governments established under the LGO 2001 as representative of the 'dictatorial' interests and according to their perceptions, the local governments represented a class of 'collaborative politicians' detrimental to their political interests.

In democratizing contexts (apt in the case of Pakistan, but also selectively applicable in other contexts) the rational incentives of the established political interests at the provincial and central level of governments are skewed against the establishment of democratic local governments, as they are seen as a competition for power and patronage (Cheema, 2006). Illustrative of this assertion, is the conduct of the elected representatives of the political parties at the central and provincial legislatures in Pakistan, who have committed (with doubtful credibility) to the reform local democratic governments and even passed legislations in this regard but the implementation continues to be deferred on different pretexts. For instance, since 2008 there have been 6 bills presented in the provincial assemblies of Punjab (main political base of the PML-N) and Sindh (main political base of the PPP) for establishing local governments and subsequently ratified into legislations, but the implementation continues to be delayed on the pretexts of developing the institutional, legal and fiscal modalities of local governemnts and inter-governmental models before allowing the structural existence of the local governments. Some political parties, like the MQM (Muttabida Quomi Movement / National Allied Movement) who have a regionally and ethnically concentrated political base in the urban regions of the Sindh province (of vital economic significance to Pakistan), to persist with their demands for local governments as it would enable a stronger bargaining position for them to seek 'political rents' in the form of ministerial incumbencies at the central level. The temporal pattern of MQM's articulation substantiates the assertion of 'political rent-seeking behavior' as it always brings up the Local Government debate (often through street agitations and even violent actions) whenever politically expedient or whenever their narrow political interests are challenged by the Provincial Government led by the PPP (with a predominantly rural political base, but with desires of gaining greater political and fiscal influence in the urban areas). Given these factors, the aversion of the civilian dispensations to elected local governments can 
also be understood as their perception of local governments as a 'bargaining-power' tool rather than their more substantive implications of democratization, accountability and responsiveness.

Much of this resistance to electoral democracy at the local levels also finds its roots in the 'limited access' / elitist structure and organization of the established political parties in the Pakistani political space. The political parties in Pakistan are, in their organization and functioning, "highly centralized and their national and provincial leadership exercises substantial control on all legislative nominations and strategic decision-making" (Cheema, Khan \& Myerson 2013). Built mainly on the basis of elite coalitions and patron-client dynamics, the organizational structure of these political parties does not extend down to the grass-roots level, and where it does the structures act as reinforcements or executors of the agendas of the higher levels of the party. A cross-country Democratic Accountability Survey conducted under the auspices of Duke University posits that the Pakistani political parties are characterized by high levels of organizational centralization and average levels of organizational extensiveness (Kitschelt and Palmer 2010; Cheema, Khan \& Myerson 2013). The survey observations further reaffirmed the similarity of these dimensions across the 5 main political parties in the country (PPP, PML-N, JUI, JI, MQM). The barriers to entry in the federal and provincial political space, are also reinforced because of the absence of local democratic politics which is both a result of and support to, the high dynastic dominance in the political parties in particular and political space in general.

The introduction of local democratic politics and local governance based on genuine participation and democratic norms would not only help in democratic consolidation but also reduce the barriers of entry in the political space at the national and provincial levels. This consolidation could also be a deterrent to any future attempts at non-democratic attempts at gaining incumbency, as historically the political vacuum at the local level has been the main source for the political legitimacy of the military regimes.

\section{Local Governance Ordinance 2001}

Upon assuming the government through a military coup in 1999, General Musharraf stipulated a 7-point agenda as a basis for the structural overhaul of the political and economic landscape of Pakistan. The seven point reform agenda included ${ }^{\mathrm{IV}}$ : 
i. Reinvigoration of national confidence and morale through socio-economic reforms;

ii. Strengthen the Federation, remove inter-provincial harmony and restore national cohesion;

iii. Devolution of power to the grassroots level;

iv. Revive Economy and restore investor confidence;

v. Ensure equal access to law, order and speedy dispensation of justice;

vi. Depoliticize state institutions to curtail rampant corruption and nepotism;

vii. Ensure swift, transparent and across the board accountability.

Given the stipulation of a reformative vision at the outset of his tenure, a National Reconstruction Bureau (NRB) was established soon after with the explicit mandate of creating a decentralization framework for the devolving fiscal and administrative authorities to the grass-root levels. The local governance reform was initiated in August 2001 under the Local Government Ordinance (2001), which legally had the value of a Presidential directive under the Provisional Constitutional Order (PCO), but not safeguarded in the national constitution of 1973. This was a fundamental weakness of the reform process right at its outset. The reforms envisaged under the LGO were more comprehensive and ambitious than those instituted under the Ayub and Zia regimes. However, they faced stiff opposition from the major political parties and the civil society organizations on account of the perceived detriment to federalism arising as a consequence of reduced provincial autonomy. This was also made a basis for rolling back the LGO in 2008 once the civilian democratically elected government gained incumbency, with the formally provided justification that it undermined the mandate and capacity of the provincial governemnts to implement its policies.

As a federation divided into four provinces (Punjab, Sindh, Balochistan, Khyber Pakhtunkhwa), a Federally Administered Tribal Area (on the Afghan Border) and a capital territory (Islamabad), the establishment of the local governments was the creation of a third layer of the governance structure. This third layer was further disaggregated into three levels; districts, tehsil (municipality), and the lowest tier was Union Council. The Union Council consists of proximate villages or towns(in urban contexts) in the Tehsil. Each administrative tier at the local level had its own council and was headed by a mayor (Nazim, in local terms) and a deputy mayor (Naib-nazim). All three levels were to be governed by 
officials coming through a process of elections. In terms of administration, as many as 10 formerly provincial departments were transferred functionally to the district and municipality level. The new arrangement had the district mayor (Nazim) assume the status of the 'executive head of the district', with a District Coordination Officer (a member of the bureaucracy) appointed by the provincial government reporting to it (Bureau 2001). Owing to the reporting structure, the district mayor was also made responsible for the performance management and stipulating the job modalities. Furthermore, the LGO also enabled the local councils to over-rule executive decisions, and empowered them to make independent decisions on all matters, with the exception of budget approvals. In the case of budget approvals, the local/district executive held considerable power over the local council, whereby it could establish standing committees to have an oversight over the activities of the local executive (Aslam and Yilmaz 2011). The local council also had the discretion to establish standing committees for monitoring of the executive's activities. The monitoring committee had an authority to suggest remedial courses of action to the local government, including the local executive (District Mayor) (Aslam and Yilmaz 2011). The functional assignment to the local government (administrative decentralization), was perhaps the main feature of the local governance systems emerging under the LGO with those existing prior to them ${ }^{\mathrm{v}}$. As compared to the preceding institutional framework in the subnational space, the provincial government performed a majority of the state functions, but under the LGO the elected local government and the provincial government were integrated at the district and municipality level, and the provincial administration or bureaucratic accountability division was abolished, with the locally serving bureaucracy accountable to the elected local government.

While the scope of the functional responsibilities of the local governments greatly increased post the LGO Devolution, along with the discretion over the allocation of expenditures and establishment of priorities, the degree of financial decentralization was largely limited. This was because districts governments were not given any revenue generation privileges and had to depend on provincial (and by extrapolation central transfers) through the provincial finance commission mechanism. Most of the district expenditure contribution was attributable to 'establishment costs' which included staff remuneration and overheads, which were under the fiscal obligation of the district governments despite them not have any control over their alteration (in terms of personnel 
recruitment or firing, cost-cutting adjustments). Furthermore, most of the devolution of power under the LGO was from the provincial to the district level amidst no transfer of powers (administrative, fiscal or political) from the central government to the subnational governments (districts and provinces included).

Prior to the Local Governance Ordinance, there was no significant inter-governmental linkage (i.e. between the Central/Provincial Governments and Local Governments), the inter-governmental conflict possibilities were minimal. However, in the aftermath of the LGO, the elected local governments had an expanded set of functional responsibilities that were previously provincial responsibilities, as well as a greater degree of control over the provincial bureaucracy (Cheema, Khwaja \& Qadir 2006). Since this devolution was instituted in the absence of any elected provincial governemnts as well as the non-partisan basis of local elections, no integrative efforts either structurally or mediatory were made to enhance provincial-local coordination, which had operational implications for both.

In addition, the indirect election of the district nazim created distortions in the incentive structures, especially since the district mayor under the LGO was most powerful actor in the local government system as the head of the executive as well as the legislative branch of the local government. Local governments in Pakistan enjoyed under the LGO enjoyed considerable discretion in the regulation of local matters, expenditure allocation for local goods, and procurement processes (Niaz (2010)). However, most of this authority was concentrated in the hands of the Nazim (Mayor). In the case of budget approval, for example, the nazim had the authority to propose the budget liable for consideration by the Local Council. This provision significantly restricted the discretion of the local council in relation to the non-elected bureaucracy and, especially, the nazim.

The incentive compatibility mechanism implicit in this arrangement was that the reelection of the mayor would be contingent upon the satisfaction of the union councils: a factor that would allow the Union Councilors to exert a greater influence over the mayor. However, in a political landscape that is dominated by individuals who control the entry into political competition and the intermediation between the state and the citizen as mentioned in the prior section, indirect election of the head of the local government unit opens up the possibility of capture of these offices by the local elite.

Given the dearth of local revenue sources, most of the local fiscal pool was financed through the fiscal transfers from the provincial and central governments under the 
Provincial Finance Commission as discussed earlier. While the horizontal distribution of these funds across local governments was formula-based (primarily based on population), the vertical distribution that determines the retained and allocable amounts was largely at the discretion of the province. The local governments also had the platforms of central transfers delivered in ear-marked forms. A pitfall of such an arrangement is that the discretionary transfers provide an incentive to the local government to respond to the preferences of the center in order to get access to funds, rather than to their constituency (Yelmaz 2010). As a result, the central governments/political actors have a greater scope for patronage and clientilistic conduct by linking transfers to political considerations. This ends up reinforcing and perpetuating existing, sub-optimal power structures and strengthens the patronage relationships, and can become an effective channel of rent distribution.

Finally, the main structural flaw with the decentralization under the LGO was that it was developed and instituted in a context when the Constitutional framework was held in abeyance. Despite the new governance structure instituted under the LGO (2001) and its subsequent ratification by the $17^{\text {th }}$ Constitutional Amendment in 2003, Pakistan continued to constitutionally be a "two-level federal state i.e. the local governments are not recognized as an established third tier of government by the 1973 Constitution" (Shah, 2012). While the $17^{\text {th }}$ Amendment was initially aimed at constitutionally ratifying and sustaining the establishment of a third tier of the state at the local levels, it ended up allowing their establishment for a 6 year period. During this 6 year period, the provincial governments could make any changes to the legislations regarding Local Governments with the approval of the President (Bureau 2001; Shah 2012). The implicit feature of this was that at the end of the 6 year period, the provincial governments were to decide whether or not the local governance structures were to be retained, and if so, what revisions to the legislation were to be introduced. This was, in fact, the main provision employed by the subsequent civilian government to roll-back the Local Governance frameworks under the $17^{\text {th }}$ Amendment. 


\section{The $18^{\text {th }}$ constitutional amendment}

Given the political dynamics of Pakistan, any political decentralization to the local levels in the current structural context does not seem probable or even possess prospects of sustainability. With the civil-military oscillations in the control of the state, there has been a renewed engagement in the national political narrative in the aftermath of the 2008 elections with Constitutionalism. Agreed upon by all political parties, the new narrative extols the execution of all functions of the state, transitions and distributions of the powers, government transitions and inter-governmental dynamics to be governed and conducted under the stipulated constitutional framework. Where inadequate, revisions to the constitutions can be made following a $2 / 3^{\text {rd }}$ majority support across all provincial and national legislative bodies. Decentralization, in the backdrop of this narrative, has assumed administrative and fiscal forms predominantly with the political decentralization only occurring at the centre-provincial level. Nevertheless, as a reform in progress and amid increasing articulations of democratic local governance returning into the national political narrative post 2013 general elections, there exists a possibility of democracy re-appearing in the local space.

The first constitution of Pakistan promulgated in 1956, envisaged Pakistan as a "decentralized federation with significant fiscal and administrative responsibilities being assumed by the lower levels of government" (Shah 2012). The central government, on the contrary, was given a greater discretion over developing its revenue base requisite for direct federal expenditures and transfers to ensure standardization of public service delivery and redistribution to ensure inter-regional equity. The current constitutional framework when first instituted in 1973, enhanced the centralization tendencies in public spending responsibilities, and also stipulated service delivery responsibilities across the two tiers of the government under Federal Legislative List and the Concurrent Legislative List (Joint responsibility of centre and province). Table 1 provides an overview of the fiscal and functional responsibilities of the federal and subnational governments as stipulated in the 1973 Constitution prior to the $18^{\text {th }}$ Amendment. The objective behind the establishment of these lists was to delineate responsibilities as well as enable an interim period whereby with the central equalization efforts, the provincial governments build their fiscal and administrative capacities to assume these responsibilities fully (Shah, 2006). Nevertheless, 
the centre continued to encroach on the responsibilities and privileges of the provinces, the provinces in turn on the local governments, and hence the division of responsibilities and the fiscal endowments requisite to deliver on those responsibilities emerged as an main issue of contention in Pakistan, owing to which an institutional mechanism of National Finance Commission was rolled into action.

The first deliberated and consensually agreed National Finance Commission (NFC) Award in 1991 geared towards granting an "unconditional access" to a greater pool of the federal divisible pool (Pasha and Shah 1996; Shah 2012). Important facet of this award was the initiation of the process of expenditure realignment aimed at granting provinces a greater discretion over the 'concurrent' responsibilities, but this occurred without any discretion over additional or new revenue stream. This resulted in further increasing the reliance of the provinces on the central transfers. As per this 1991 award, which continued to be the revenue distribution formula till 2001, the federal transfers to the provinces financed a greater portion of the provincial operating expenditures and in the case of Balochistan the transfer financing amounted to $99 \%$ of the provincial expenditure (Shah, 2007). This process was reversed under the LGO and the PCO discussed earlier, where the centre's pursuit of diluting established political support devolved both resource endowments as well as functional responsibilities from the provincial to the local governments. While the reforms under the LGO did result in service delivery improvements at the local levels, they were considered incomplete in the sense that they did not rationalize the federal and provincial powers, and in effect led the centre to encroach on both federal and provincial responsibilities (and hence resources) as stipulated in the 1973 constitutional framework. 
Table 1: 1973 Constitution Legislative and Functional Responsibilities of Public Service Goods

\begin{tabular}{|c|c|c|}
\hline Legislative Responsibility & Services & $\begin{array}{l}\text { Actual Allocation of } \\
\text { Functions }\end{array}$ \\
\hline Federal Government $^{1}$ & $\begin{array}{l}\text { Defense, External Affairs, Posts and Telegraphs, Telephones, } \\
\text { Radio and T.V., Currency, Foreign Exchange, Foreign Aid, } \\
\text { Institutes for Research, Nuclear Energy, Ports and } \\
\text { Aerodromes, Shipping, Air Service, Stock Exchange, } \\
\text { National Highway, Geological Surveys, Meteorological } \\
\text { Surveys, Censuses, Railways, Mineral Oil \& Natural Gas } \\
\text { Industries }\end{array}$ & Federal Government \\
\hline $\begin{array}{l}\text { Federal/ Provincial } \\
\text { Governments }^{2}\end{array}$ & $\begin{array}{l}\text { Population Planning, Curriculum Development, Syllabus } \\
\text { Planning, Centers of Excellence, Tourism, Social Welfare, } \\
\text { Vocational/Technical Training, Employment Exchange }\end{array}$ & $\begin{array}{l}\text { Federal/Provincial } \\
\text { Governments }\end{array}$ \\
\hline Provincial Government & $\begin{array}{l}\text { Historical Sites and Monuments, Law and Order, Justice, } \\
\text { Tertiary Health Care and Hospitals, Highways, Urban } \\
\text { Transport, Secondary and Higher Education, Agricultural } \\
\text { Extension, Fertilizer and seed distribution, Irrigation, Land } \\
\text { Reclamation }\end{array}$ & Provincial Governments \\
\hline Local Governments ${ }^{3}$ & $\begin{array}{l}\text { Primary Education, Curative Health, Preventive Health, } \\
\text { Water Supply Drainage and Sewage, Farm-to-Market Roads, } \\
\text { Land Development, } \\
\text { Rural Developments, Link Roads, Intra-Urban Roads, Street } \\
\text { Lighting, Garbage Collection, Fire Fighting, Parks and } \\
\text { Playgrounds }\end{array}$ & $\begin{array}{l}\text { Primarily Provincial with } \\
\text { Minor Local Government } \\
\text { Involvement } \\
\text { Local Governments }\end{array}$ \\
\hline
\end{tabular}

1. According to Federal Legislative List

2. According to Concurrent Legislative List

3. According Provincial Legislation

Source: Shah(2009) Constitution of the Islamic Republic of Pakistan 1973 (Sch. Including $17^{\text {th }}$ Amendment)

With the transition back to civilian democratic government in 2008, the consensual narrative across the political space was to 'uphold democratic norms' by re-strengthening the provinces and rolling back the governance reforms under the LGO. The outcome of this consensual commitment to also led to the $7^{\text {th }}$ National Finance Commission Award in 2009 (for the period 2010-2015), whereby the smaller provinces were given a greater share to the resource pools in a bid to build inter-provincial harmony and also meet the equalization requisites. Under the $7^{\text {th }}$ NFC, an enhanced allocation was given to the smaller provinces. Indicators such as population density, poverty levels, and domestic fiscal effort were incorporated as determinants of the fiscal revenue sharing formula. 
Table 2: Finance Decentralization under the $7^{\text {th }}$ NFC Award

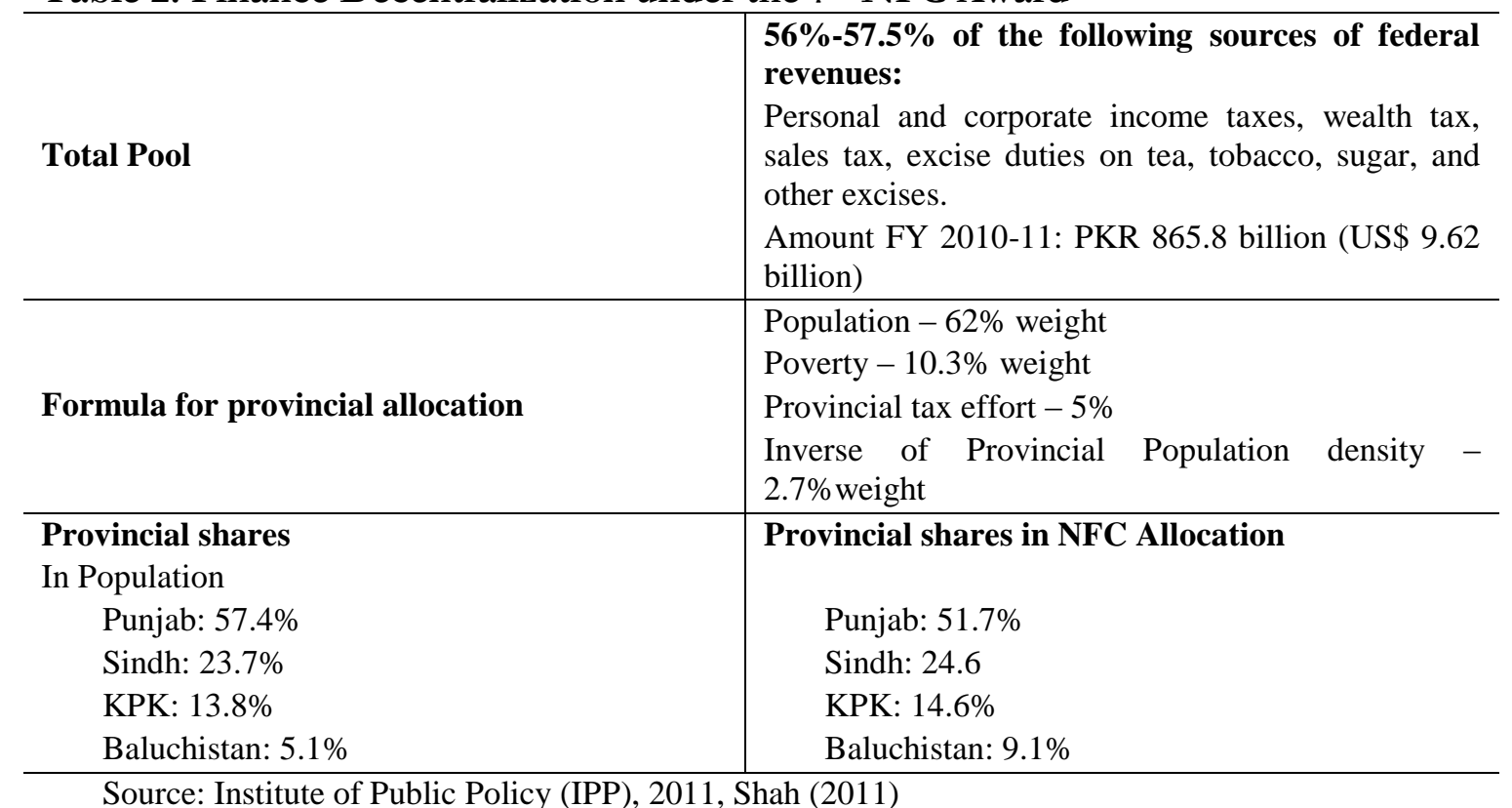

In terms of its institutional dimensions, the $18^{\text {th }}$ Amendment substantially reformed the institutions established as intergovernmental coordination mechanisms, i.e. the Council of Common Interests (CCI) and the National Economic Council (NEC). The CCI is a coordination and deliberative body headed by the Prime Minister (or a designate), the Chief Ministers of all provinces and federal government representatives. While its prior jurisdiction was nominal in terms of providing solicited provincial input in federal matters, the $18^{\text {th }}$ Amendment enhanced its potency by making it responsible for all matters related to the federation ${ }^{\mathrm{VI}}$. The NEC, also a constitutionally mandated body for oversight over national economic policies, previously composed of the Prime Minister, and Presidentially nominated members (with the constraint holding that at least one representative of each province must be nominated). In the aftermath of the $18^{\text {th }}$ Amendment, the composition was altered to enable a greater influence of the provincial governments such that two provincial members in addition to the provincial Chief Minister and four federal government representatives nominated by the Prime Minister would now compose the NEC. This has enabled a greater deliberative scope for the provincial interest articulation in the national policy making, to avert any scope for centralized high-handed policy stipulations. 
Furthermore, this Constitutional amendment also enabled substantive changes in the division and devolution of powers between the federal and provincial levels of the government whereby the previously entrenched 'Concurrent List' was disposed off altogether, and a functional reassignment to the Federal Government was done contingent upon the directions of the CCI, with all other functions devolved to the provinces.

Table 3: Functional Responsibilities under the $18^{\text {th }}$ Amendment Federation/CCI (Joint Federal-Provincial) Tasks-Federal Legislative List Part II

\begin{tabular}{|c|c|}
\hline Electricity & $\begin{array}{l}\text { Provincial police operations beyond provincial } \\
\text { boundaries }\end{array}$ \\
\hline Minerals, oil and natural gas & Industrial policy \\
\hline Railways & $\begin{array}{l}\text { National Planning and National Economic } \\
\text { Coordination }\end{array}$ \\
\hline Major Ports & Coordination of Scientific and Technological Research \\
\hline Census & All regulatory authorities under a federal law \\
\hline Public Debt & $\begin{array}{l}\text { Standards in higher education and Research, scientific } \\
\text { and technical institutions }\end{array}$ \\
\hline $\begin{array}{l}\text { Federal corporate entities including Water and } \\
\text { Power Development Authority and Pakistan } \\
\text { Industrial Development Corporation } \\
\text { Legal, medical and other professions }\end{array}$ & Interprovincial matters and coordination \\
\hline \multicolumn{2}{|c|}{ Federal Functions — Federal Legislative List Part I } \\
\hline Defense & International and inter-provincial trade \\
\hline External Affairs and international treaties & Nuclear Energy \\
\hline Immigration and citizenship & $\begin{array}{l}\text { Airports, aircraft, air navigation, air and sea travel and } \\
\text { shipment, lighthouses }\end{array}$ \\
\hline Post and Telecommunications & Patents, trademarks, copyrights \\
\hline Central banking, Currency, Foreign Exchange, & Stock exchanges and futures markets \\
\hline $\begin{array}{l}\text { Corporate regulation including banking and } \\
\text { insurance }\end{array}$ & National highways and strategic roads \\
\hline Fishing beyond territorial waters & $\begin{array}{l}\text { Federal geological surveys and meteorological } \\
\text { organizations }\end{array}$ \\
\hline Standards of weights and measures & Local government in cantonment areas \\
\hline
\end{tabular}

Provincial Responsibilities

All residual functions

Local Government Responsibilities: By provincial government determination

Source: Constitution of the Islamic Republic of Pakistan, Shah 2011, Schedule IV (Post $18^{\text {th }}$ Amendment) 
Notwithstanding the functional reassignments and devolution, there has been very limited reassignment of taxation responsibilities to the provincial governments. The taxation powers remain predominantly with the central government, which were further reaffirmed by the provincial governments owing to the scale advantage argument (Yelmaz 2010). Under the current framework, the federal government continues to impose taxation on sale and purchase of goods, on capital gains, and financial assets. However, the central government had to relinquish revenue generation privileges from immovable property, estate and bequest taxation, VAT on services (still not in effect though multilateral negotiations on tax reforms are ensuing), and zakat and ushr (religious taxes on income and land holdings) (FBR, 2011).

In terms of the provincial exposure to capital mobilization avenues, the $18^{\text {th }}$ Amendment also enables the subnational governments to access domestic and international sources for credit and finance, albeit within the parameters defined by the NEC. These limits continue to be revised circumstantially and are not mandated at fixed rates in a legal framework as observed in the '80-20 rule' as practiced in Bolivia. In addition to enhanced avenues of credit finance, under this amendment the provincial governments were also equipped with a relatively more dynamic and buoyant tax base in the form of sales tax on services. In 2013, the fiscal proceeds from this tax base alone generated around $0.5 \%$ of the GDP in fiscal revenues(IPP, 2013 and Government of Pakistan, 2013). Other avenues of provincial fiscal inflows through taxation include agricultural income taxes. However, these have been of a limited yield historically due to evasion, non-compliance and inadequate enforcement often due to the strong political influence that this sector commands (IMF, 2013). For instance, the provincial governments have been empowered to collect agricultural taxes since 1997 , whereby the presumptive tax rate applied was a static real amount of PKR 150-250 per acre, or US\$ 1.5-2.5 per acre/annum (depending on the land quality) and the penalty for non-compliance also at a miniscule level of Rs. 1000 (US\$ 10 in 2014 rates).As per IPP (2013) estimates, generating sufficient revenues for the provincial fiscal pools requires that at least $20 \%$ of the income from large farm (more than 25 acres) must be established as the effective tax rate, along with a tangible and credible punitive action against non-compliance. However, the histrocially preferential treatment to the agricultural income tax still persists and the current constitutional framework even in the aftermath of the $18^{\text {th }}$ Amendment does little to reverse it. 
Enabling the provinces to raise additional revenues through capital value taxation on properties, puts forth an under-exploited revenue base and this has not been a result of the provinces not having the requisite resources for indigenous revenue mobilization but more a consequence of the lack of adequate incentives given the dependence on the NFC transfers (Shah, 2012). The current system also established 2015 as a milestone for transforming the governance structures such that the power concentration at the central level is replaced by concentration at the subnational level. Under this milestone, all major economic and social functions shall be performed and designed by the provinces. This is exhibited in the shifting trends in the financial and functional pools of the provincial governments as illustrated in Tables 4 and 5 .

Table 4: Summary of Fiscal Decentralization under the $18^{\text {th }}$ Amendment

\begin{tabular}{llll}
\hline Fiscal Year & Indicator & Federal Share & Provincial-Local Share \\
\hline FY 2009-10 & Revenue collection & $94 \%$ & $6 \%$ \\
& Revenues retained & $65 \%$ & $35 \%$ \\
& Expenditure share & $66 \%$ & $34 \%$ \\
& Residual Fiscal Gap after transfers & $-1 \%$ & $+1 \%$ \\
\hline FY 2011-12 & Revenue Collection & $90 \%$ & $10 \%$ \\
& Revenues retained & $61 \%$ & $39 \%$ \\
& Expenditure share & $64 \%$ & $36 \%$ \\
& Residual Vertical Fiscal Gap after & $-3 \%$ & $+3 \%$ \\
& transfers & & $15 \%$ \\
& Revenue collection $2014-15$ & $85 \%$ & $55 \%$ \\
& Revenues retained & $45 \%$ & $55 \%$ \\
& Expenditure share & $45 \%$ & $0 \%$ \\
& Residual Vertical Fiscal Gap after & $0 \%$ & \\
\hline
\end{tabular}

Source: economic Survey of Pakistan 2011, Shah 2011/2012, IMF Government Finance Statistics Module

Amongst this functional devolution, there has also been a dispensing away of viable central roles like fostering a mutually beneficial economic union, protecting minorities and disadvantaged groups, disaster response and risk mitigation, and framing an overall strategic developmental orientation. Particularly, in the context of political and economic cohesion, it is imperative that natural resource endowments are viewed as national subjects instead of being made into provincial realms such that the rents from these resources can be invested at a higher scale of effect and equity at the central level. The current framework makes it into a provincial subject, which has potential for divisive pressures between the provinces and hence expose the federation to risk. This argument finds its roots in the inter-provincial conflict over Hydel ressource distribution and the Kalabagh Dam 
construction, as well as the distribution of gas and extractive revenues across the provinces. Especially considering the latter, the divisiveness is particularly pronounced in Baluchistan which is host to a substantial mineral and extractives base yet deriving the least benefit. A decentralized system works best if there are potent platforms for interest articulation by the citizenry (through effective political decentralization), and a finance-functional harmony. Particularly important is to ensure that expenditure decentralization must also be accompanied by the taxation/revenue generation decentralization such that reliance on higher level transfers is reduced and also create greater incentives for fiscal transparency and accountability.

Table 5: Changes in the Direct Expenditure Obligations as a result of $18^{\text {th }}$ Amendment

\begin{tabular}{|c|c|c|c|c|c|c|c|c|}
\hline \multirow{2}{*}{$\begin{array}{l}\text { Expenditure } \\
\text { Function }\end{array}$} & \multicolumn{3}{|c|}{ Fiscal Year 2009-10 } & & \multicolumn{3}{|c|}{ Fiscal Year 2014-15 } & \multirow[b]{2}{*}{ Total } \\
\hline & Federal & Provincial & Local & Total & Federal & Provincial & Local & \\
\hline Defense & $100 \%$ & $0 \%$ & $0 \%$ & $100 \%$ & $100 \%$ & $0 \%$ & $0 \%$ & $100 \%$ \\
\hline $\begin{array}{l}\text { Public Order and } \\
\text { Safety }\end{array}$ & $30 \%$ & $70 \%$ & $0 \%$ & $100 \%$ & $30 \%$ & $70 \%$ & $0 \%$ & $100 \%$ \\
\hline $\begin{array}{l}\text { Economic } \\
\text { Services }\end{array}$ & $26 \%$ & $50 \%$ & $\%$ & $100 \%$ & $10 \%$ & $66 \%$ & $\%$ & $100 \%$ \\
\hline $\begin{array}{l}\text { Recreation, } \\
\text { Culture and } \\
\text { Religion }\end{array}$ & $53 \%$ & $32 \%$ & $\%$ & $100 \%$ & $5 \%$ & $80 \%$ & $\%$ & $100 \%$ \\
\hline Education & $14 \%$ & $23 \%$ & $\%$ & $100 \%$ & $5 \%$ & $33 \%$ & $\%$ & $100 \%$ \\
\hline Health & $9 \%$ & $51 \%$ & $\%$ & $100 \%$ & $5 \%$ & $55 \%$ & $\%$ & $100 \%$ \\
\hline
\end{tabular}

Source: World Bank Reports, Shah 2012 
Furthermore, the current constitutional framework post the $18^{\text {th }}$ Amendment does not revisit the mechanisms in place for central fiscal transfers to provincial governments under the NFC award. These NFC awards are guided, as mentioned earlier, by the objectives of fiscal equalization horizontally and vertical gap reduction. However, with the functional devolution of the social service provision and infrastructural development to the provincial levels, the role of the federal government in finance provision and establishment of minimum standards is important. Yet, there is no instrument available under the current framework that enables the federal government to influence the absorption of its fiscal allocations in pursuit of the broader national developmental objectives.

\section{Conclusion and outlook}

The LGO and the $18^{\text {th }}$ Constitutional Amendment have both been substantive attempts at subnational empowerment; with the former less than the latter by virtue of the absence of the constitutional cover and its autocratic sponsors. Despite having its merits, LGO has little formal relevance in the current scheme of decentralization and federalism discourse in Pakistan. The $18^{\text {th }}$ Amendment, thus emerges as the most recent and comparably expansive decentralization reform that has fostered an environment conducive for federalism. Perhaps the greatest merit of this round of reform has been the underlying political consensus and its constitutional embeddedness. Whether or not the current decentralization from the centre to the provincial levels also leads to provincial to local decentralization in the subsequent rounds remains to be seen, but in terms of fostering a greater national cohesion and deepening democracy it does exhibit potential. In addition, a clearer delineation of the functionalities has reduced the scope for arbitrary unwarranted federal intervention in provincial subjects, thus reducing the centre-provincial frictions. The institutional reinvigoration of the CCI, for example, is another important outcome of this amendment, as it creates inter-governmental deliberative platforms that can be used for grievance redressal. Furthermore, it also fosters subnational interest articulation that was previously inhibited by federal unilateralism. The key shift in the current constitutional framework puts the provinces at the core of both policy formulation and its implementation, which not only makes the governance structure more proximate to the citizenry but also clarifies which levels must be held accountable for any suboptimalities in 
service delivery. The greater proximity of the government to the citizenry enabled by the $18^{\text {th }}$ Amendment may also lead to a relatively higher level of citizen participation in the public policy frameworks while also creating greater pressures for accountability and responsiveness by the governments to the citizens which would be further enhanced if local levels also came to the fore.

The amendment's predominant engagement with the devolution of functionalities and linking the fiscal endowments at the expense of any rationalization of the mandates of central and provincial functions and discussion on local governance structures or division of the provinces into smaller administrative units. To an extent, the 18th Amendment may have unintentionally compounded these threats by reasserting an obsolete model of twotier federal governance. Instead of a disparately powerful centre, under the $18^{\text {th }}$ Amendment it is a disparately powerful province. The extent to which the increased authorities at the provincial levels have led to a corresponding improvement in the public service delivery or even grappling with the challenges to the state in terms of rule and order, is suboptimal.

On the whole, federalism in Pakistan may have taken the most substantive of its leaps with the $18^{\text {th }}$ Amendment, there are some downside risks that can prove highly detrimental if not dealt with caution. The overall focus of all political actors, the central and provincial governments has to foster greater inter-regional harmony to ensure state stability and cohesion. The recent general elections in 2013 have resulted in a dynamic and pluralized political landscape in Pakistan, which is a welcome sign. However, with the enhanced provincial autonomy and opposing political parties holding office in three of the four main regions, there exist divisive risks too. The 18th Amendment stands well on the grounds of democratic consolidation but it cannot be considered a panacea for the governance constraints of Pakistan as it is at best an incomplete process - completion of which would deem imperative more fundamental reforms that ensure greater public responsiveness but also a stable political and economic union due to greater efficiencies and accountability mechanisms.

\footnotetext{
* University of Trento.

I The provisions and details have been derived for analysis from the Constitutional Archives and Schedules available at www.na.gov.pk and Constitution of Pakistan published schedules.

II Present day Bangladesh.

III As of IV Schedule.
} 
IV Taken from Presidential Address to the Nation 17th October 1999. (Archive video).

$\mathrm{V}$ The local governments established during the 1980s under the Zia regime were mostly suspended during the 1990s so in fact prior to the current devolution there were no elected representatives at the local level and their powers were exercised by provincial bureaucrats as local government administrators.

VI The composition remained the same as before (Prime Minister, all Chief Ministers and three nominated Federal Government Representatives), but the scope of responsibility was expanded to include decision making, monitoring, supervision, and control responsibilities over the Federal Legislative List Part II, which includes the following: railways; minerals, oil, and natural gas; hazardous materials; industrial policy; electricity; major ports; federal regulatory authorities; national planning and economic coordination; supervision and management of public debt; censuses; provincial police powers beyond provincial boundaries; legal matters; regulation of the legal, medical, and other professions; standards in education and research; interprovincial coordination; and conflict resolution (IPP, 2011).

\section{References}

- Aslam Ghazia and Yilmaz Serdar, 2011, "Impact of Decentralization Reforms in Pakistan on Service Delivery", Public Administration and Development, XXXI(3): 159-171.

- Bennmessaoud Rachid, Basim Uzma, Cholst Anthony \& López-Calix Jose R., 2013, Pakistan: The Transformative Path, World Bank Resident Mission Pakistan, Islamabad.

- $\quad$ Burki Shahid Javed, Perry Guillermo \& Dillinger William R., 1999, Beyond the Center: Decentralizing the State, World Bank Publications, Washington, DC.

- Cheema Ali and Mohmand Shandana Kahn, 2008, "Decentralization and Inequality in Pakistan: Bridging the Gap that Divides", in Ali Syed Mubashir and Saqib Muhammad Amjad (eds), Devolution and Governance Reforms in Pakistan, Oxford University Press, Karachi.

- Cheema Ali, Khwaja Asim Ijaz and Qadir Adnan, 2006, "Local government reform in Pakistan: Context, Content, and Causes", in Bardhan Pranab and Mookherjee Dilip (eds), Decentralization and Local Governance in Developing Countries, MIT Press, Cambridge (Mass.), 257-284.

- Constitution of Pakistan, 1956 - Constitutional Archives of Pakistan II Schedule.

- Constitution of Pakistan, 1962 - Constitutional Archives of Pakistan II Schedule.

- $\quad$ Constitution of Pakistan, 1973 - Various Schedules.

- Crook Richard C. \& Manor James, 1998, Democracy and Decentralisation in South Asia and West Africa: Participation, Accountability and Performance, Cambridge University Press, Cambridge.

- Haq Nadeem, 2010, "Pakistan: A failed state?”, IFPRI, Washington, DC.

- Institute of Public Policy, 2011, "State of the economy: Devolution in Pakistan - Fourth annual report", Cross Media, Lahore, Pakistan.

- $\quad$ Keefer Philip E., Narayan Ambar and Vishwanath Tara, 2006, "Decentralization in Pakistan: Are Local Governments likely to be more Accountable than the Central Government", in Bardhan Pranab and Mookherjee Dilip (eds), Decentralization and Local Governance in Developing Countries, MIT Press, Cambridge (Mass.), 285-303.

- Kitschelt Herbert and Palmer Damon, 2010, Democratic Accountability and Linkages Project, Department of Political Science, Duke University, referred resource accessible at https://web.duke.edu/democracy/data.html.

- Musgrave Richard A., 1961, “Approaches to a Fiscal Theory of Political Federalism”, NBER (97134). Karachi.

Niaz Ilhan, 2010, The culture of power and governance of Pakistan 1947-2008, Oxford University Press,

- Oates Wallace, 2005, “Toward A Second-Generation Theory of Fiscal Federalism”, International Tax and Public Finance, XII(4): 349-373.

- $\quad$ Pakistan, Ministry of Finance. (2011a). Pakistan budget 2010/11. Islamabad, Pakistan.

- Pakistan, Ministry of Finance. (2011b). Pakistan economic survey 2011-12. Islamabad, Pakistan.

- Pasha A. Hafeez, 1997, 'Fiscal Decentralization: Lessons from the Asian Experience', Social Policy 
and Development Centre, Research Report 19.

- $\quad$ Program, U. N. (2014). Human Development Report. UNDP.

- Shah Anwar, 2011, "Federalism reform imperatives, restructuring principles and lessons for Pakistan”, Pakistan Development Review, XXXVI(4): 499-536.

- Shah Anwar, 2012, “Making Federalism Work”, World Bank Policy Paper Series , November 2012.

- Shahid Zubair, 2013, "Understanding Institutional Inadequacies and Reform Imperatives in Pakistan", Pakistan Development Review (forthcoming).

- The Constitution of the Islamic Republic of Pakistan. (2010). Karachi, Pakistan: Ideal Publishers.

- Weingast Barry R., 2009, "Second generation fiscal federalism: The implications of fiscal incentives", Journal of Urban Economics, LXV(3): 279-293. 